\title{
Corneal specular microscopy in infectious and noninfectious uveitis
}

\author{
Microscopia especular de córnea em pacientes com uveítes \\ infecciosas $e$ não-infecciosas
}

\author{
Filipe de Oliveira ${ }^{1}$ \\ Ana Carolina de Oliveira Motta ${ }^{2}$ \\ Cristina Muccioli ${ }^{3}$
}

\begin{abstract}
Purpose: Involvement of the cornea endothelium during uveitis has not been extensively studied even though it might participate in or constitute a target of ocular inflammation. Formation of keratic precipitates (KP) is a characteristic finding in several forms of uveitis. The aim of this prospective study was to examine the vicinity of keratic precipitates in infectious and noninfectious uveitis by specular microscopy. Methods: Patients with infectious and noninfectious uveitis in any activity level and presence of keratic precipitates were enrolled. The mean age was 40.5 years ( \pm 14.2 years). A Topcon SP-2000P noncontact specular microscope was used to capture endothelial images in the vicinity of keratic precipitates. Automated morphometric analysis was done for cell size, cell density and cells coefficient of variation. Statistical comparisons were made between the infectious and noninfectious groups. Results: From the 25 patients enrolled in this study, 16 (44\%) eyes presented infectious uveitis, $19(53 \%)$ noninfectious uveitis and $1(3 \%)$ eye was excluded due to the impossibility to obtain a specular image. The mean cell density estimated was 2,628 \pm 204 cells $/ \mathrm{mm}^{2}$ in infectious group and 2,622 \pm 357 cells $/ \mathrm{mm}^{2}$ in noninfectious group. The mean cellular area in infectious and noninfectious group was respectively $385 \pm 31 \mu \mathrm{m}^{2}$ and $390 \pm 60 \mu^{2}$. The coefficient of variation $(\%)$ of the cellular area in the vicinity of keratic precipitates was $26.36 \pm 3.44$ in infectious and $27.69 \pm 4.61$ in noninfectious group. The differences between the groups were not statistically significant $(\mathrm{P}<0.005 / \mathrm{Mann}$-Whitney test) for the three morphologic variables. Conclusion: The clinical applicability of specular microscopy in patients with uveitis can be an useful tool to evaluate the corneal endothelium in the presence of keratic precipitates, however the handicap of the specular image formation might not be discarded in some cases. The differences found were not clinically meaningful between the infectious and noninfectious groups, however the uveitis in various degrees of intraocular inflammation and the relatively small number of patients in each clinical category of this study, indicates that further studies can be required to evaluate better the morphology of the endothelium.
\end{abstract}

Keywords: Corneal topography; Endothelium, corneal; Uveitis; Microscopy/methods; Precipitation

\section{INTRODUCTION}

Uveitis is an ocular condition characterized by intraocular inflammation and usually caused by several etiologies ${ }^{(1)}$. It can have severe visual reper- 
cussions if not diagnosed and treated appropriately, and represents an important cause of blindness and ocular morbidity in many countries including Brazil and the United States ${ }^{(2)}$. In clinical practice, the main issue is to evaluate the severity of uveitis and determine its etiology (infectious or inflammatory) to propose the most appropriate therapy. Involvement of the cornea, notably the endothelium, during uveitis has not been extensively studied even though it might participate in or constitute a target of ocular inflammation. Formation of keratic precipitates (KP) is a characteristic finding in several forms of intraocular inflammation. Typically KP are created by the small aggregates of inflammatory cells accumulated on the corneal endothelial surface ${ }^{(3)}$. Clinical aspects of these KP can provide useful information on etiology and degree of inflammatory activity. The KP are said to be granulomatous when they are large, and they might be secondary to etiologies such as sarcoidosis, tuberculosis or toxoplasmosis. Other precipitates are called nongranulomatous when they are small, for example in HLA-B27 associated anterior uveitis and Behçet's syndrome ${ }^{(4)}$.

Although recently KP was analysed using in vivo confocal microscopy; the technique requires a coupling gel to reduce light scattering at the corneal epithelium and it is not readily performed in all clinics as well as the number of machines in use remains limited ${ }^{(5)}$. The noncontact specular microscopes are better tolerated by patients and are preferred by physicians, they do not require corneal contact, are quicker and easier to use, and current equipped with auto-focus and built-in image analysis softwares ${ }^{(6)}$. In a specular microscopy an image of the corneal endothelium is obtained after light refraction at anterior corneal surface. It is known like specular image and the endothelium appearance can be expressed by some morphologic variables: mean cell density, mean cell area and cellular area coefficient of variation. The aim of the present study was evaluate these variables in the vicinity of the KP in infectious and noninfectious uveitis obtained by an usual noncontact specular microscope.

\section{METHODS}

This was a prospective study of 25 patients with mean age of $40.5( \pm 14.2)$ years who were examined at the Uveitis Sector of the Ophthalmology Department at the Federal University of São Paulo. Informed consent was obtained from all subjects for their participation in the study. Patients with previous ocular surgery, trauma, contact lens use history, corneal dystrophy, corneal edema, high intraocular pressure and any other anterior segment disorders affecting the corneal endothelium were excluded from the study. Only patients with infectious and noninfectious uveitis in any activity level and presence of KP were enrolled.

The clinical ocular diagnosis were made by two different uveitis specialists using standard departmental protocol. This included a thorough history, including extensive review of systems, ophthalmic examination and pertinent laboratory investigations. On initial examination data concerning age, gender, ocular symptoms, medications, previous surgery and systemic diseases were recorded. Every patient underwent a complete anterior and posterior segment examination. On slit lamp examination the presence of KP was noted and any number, size, nature, pigmentation and their position on the endothelium were included.

A noncontact specular microscope (SP 2000P; Topcon, Tokyo, Japan) was used to capture the endothelial images $(0.2 \mathrm{x}$ $0.5 \mathrm{~mm}$; 170x magnification on the instrument display) as previously described ${ }^{(5)}$. The patient's head was positioned on a chin rest and the patient was instructed to look straight ahead into the built-in fixation target. Endothelial images were taken three times with high flash intensity in the automatic mode from the center of the cornea and after recording, the images with good contrast were selected and stored in the device. After the manual designation, known like centre-dot method, of a minimum of 10 endothelial cells in each image in the vicinity of the KP; the cell density and cellular area were calculated by a computer program incorporated into the instrument (Figure 1). All specular microscopy examination was performed by the same investigator.

\section{RESULTS}

Of the thirty-six eyes from 25 patients enrolled in this study; $16(44 \%)$ presented infectious uveitis, $19(53 \%)$ noninfectious uveitis and $1(3 \%)$ eye was excluded of the analysis due to unattainable specular microscopy image. The patient demographics, diagnosis and slit lamp size of KP are shown in table 1.

The mean cell density estimated was $2,628 \pm 204$ cells $/ \mathrm{mm}^{2}$ in infectious group and 2,622 $\pm 357 \mathrm{cells} / \mathrm{mm}^{2}$ in noninfectious group. The mean cellular area in infectious and noninfectious group was respectively $385 \pm 31 \mu \mathrm{m}^{2}$ and $390 \pm 60 \mu \mathrm{m}^{2}$. The coefficient of variation $(\%)$ of the cellular area in the vicinity of the KP was $26.36 \pm 3.44$ in infectious and $27.69 \pm$ 4.61 in noninfectious group. All these differences were not statistically significant ( $\mathrm{p}<0.005 /$ Mann-Whitney test) for the three morphologic variables.

\section{DISCUSSION}

Specular microscopy is indicated in several specific conditions and has become widespread to evaluate situations in which the cornea is suspected of having endothelial abnormality and in which the accuracy of the estimated cell count from slit-lamp biomicroscopy is thought to be less than satisfactory ${ }^{(7)}$. These situations include but are not limited to eye banking, preoperative evaluation and corneal disease follow-up.

In uveitis the role of the corneal endothelium has not been widely studied, and little is known about the mechanisms of KP formulation, probably because the endothelium is hard to access, making investigation difficult. When the human corneal 

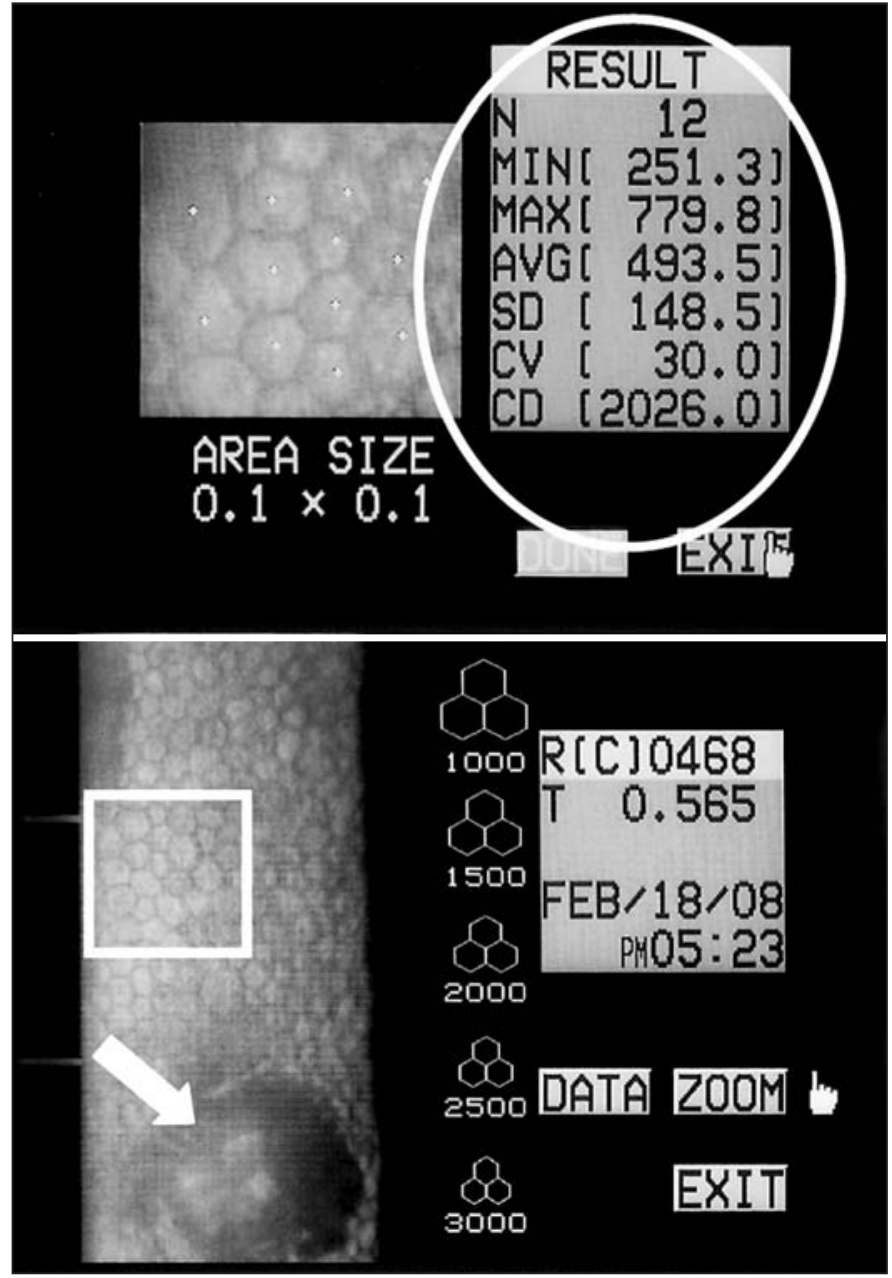

Figure 1 - A video print of the endothelium image obtained by the SP2000P from a subject enrolled in the study. The arrow indicates the keratic precipitates corresponding to the dark halo surrounding the central white deposit with indistinct cellular margins. The white-boxed region demarcates the vicinity area used for generating the morphologic variables which are indicated for the ellipse.

endothelium is damaged, healing is a process of cellular enlargement and spreading to create a contiguous layer of cells on the inner surface of the cornea. The degree of endothelium cell loss from disease, for instance, can be documented with specular microscopy as an increase in individual cell surface area and a decrease in the endothelial cell density for the cornea ${ }^{(8)}$. Endothelial abnormalities had been observed in cases of anterior and posterior uveitis. Some authors studied these abnormalities in various corneal disorders and also in uveitis with specular microscopy ${ }^{(9-10)}$. It is a well established fact that endothelial abnormalities occur in uveitis ${ }^{(11-12)}$. Some authors studied the vicinity of fresh KP and there was significant statistical difference in endothelium mean cell size and density compared with normal endothelium of the opposite eye, besides the mean endothelial cell size decreased with a corresponding increase in cell density on resolution of uveitis; the absolute values did not return to normal. The authors concluded that it might be that endothelial cells surrounding the fresh KP were larger in size either because of the stress of inflammation or due to some inflammatory mediators ${ }^{(13)}$. In our study the difference in the cell density and the mean cell size between infectious and noninfectious uveitis group was not statistically significant.

According to a recent study review ${ }^{(8)}$ for FDA clinical trials, the ideal specular microscopy study would be performed by one examiner at one clinical site with one specular microscope model. One examiner should analyze all the specular micrographs, which would give uniformity in the subjective decision of identifying cells. Furthermore, Specular Microscopy Reading Center repeatability is best achieved by one examiner. The estimated cell density can have a $\pm 2 \%$ to $\pm 5 \%$ variability. All these recommendations were followed in the present study and are crucial to standardization and minimization of variables.

In a specular microscopy an image of the corneal endothelium is obtained after light refraction at anterior corneal surface. Endothelial cell density can be estimated by counting the number of cells within a certain area, in the present study such estimation was possible in KP vicinity, only one eye was excluded of the analysis because the endothelium image was impossible, probably the specular reflex at corneal central area was not regular and smooth-surfaced because KP were very distributed along this area, making impossible the cell identification. The image quality is directly related to the identification of cell borders, which is determined by the number of cells visible in the field. Each examiner may have a different subjective ability to identify an individual cell. Other authors found that image quality evaluation of 688 images by 2 examiners was identical only $64 \%$ of the time ${ }^{(14)}$. In our study the quality of the image was considered good, each patient had three images from affected eye and they were analyzed separately, however for statistical analysis the mean from endothelial density and cellular area was considered.

The endothelial cell density analysis can be performed by comparison method, frame method (fixed or variable), corner method and center to center method. Regardless of the method, the accuracy depends on the quality of endothelial cell image to identify individual cells ${ }^{(8)}$. The present study used the centerto-center method which is a common technique incorporated into specular microscopes.

The specular microscope SP-2000P model used in this study, requires the identification of the centers of 10 or more contiguous cells in an endothelium image by pointing them out on the camera screen (clicking them with the camera mouse). As instructed by the user manual, we identified the centers of on average 15 (10-20) cells per image. The software in this model measures the distances between individual cell centers and then computes the mean endothelial cell area and hence the endothelial cell density ${ }^{(15)}$.

The particular estimation of cell area distribution usually reported is that of the coefficient of variation $(\mathrm{COV})=$ standard deviation of cell area/average cell area $\mathrm{x} 100$, which is often referred to as the degree of polymegathism and expres- 


\begin{tabular}{|c|c|c|}
\hline Patient № - Sex / Age (years) & Diagnosis & Slit lamp size of KP \\
\hline $1-F / 45$ & Tuberculosis (infectious) & Large \\
\hline $2-F / 27$ & Vogt-Koyanagi-Harada (noninfectious) & Large \\
\hline $3-M / 45$ & Ocular toxoplamosis (infectious) & Fine \\
\hline $4-F / 27$ & Vogt-Koyanagi-Harada (noninfectious) & Fine \\
\hline $5-M / 32$ & Tuberculosis (infectious) & Large \\
\hline $6-F / 62$ & Herpetic kerato-uveitis (infectious) & Fine \\
\hline $7-F / 60$ & Toxoplasmosis (infectious) & Large \\
\hline $8-M / 42$ & Toxoplasmosis (infectious) & Large \\
\hline $9-F / 31$ & Toxoplasmosis (infectious) & Large \\
\hline $10-F / 59$ & Sarcoidosis (noninfectious) & Large \\
\hline $11-M / 62$ & HLA-B27-associated uveitis (noninfectious) & Large \\
\hline $12-M / 22$ & Toxoplasmosis (infectious) & Large \\
\hline $13-\mathrm{M} / 24$ & Toxoplasmosis (infectious) & Large \\
\hline $14-F / 56$ & Vogt-Koyanagi-Harada (noninfectious) & Fine \\
\hline $15-\mathrm{F} / 27$ & Toxoplasmosis (infectious) & Fine \\
\hline $16-F / 68$ & Toxoplasmosis (infectious) & Medium \\
\hline $17-\mathrm{M} / 30$ & HLA-B27-associated uveitis (noninfectious) & Fine \\
\hline $18-\mathrm{M} / 30$ & Vogt-Koyanagi-Harada (noninfectious) & Medium \\
\hline $19-F / 41$ & Vogt-Koyanagi-Harada (noninfectious) & Fine \\
\hline $20-F / 36$ & Toxoplasmosis (infectious) & Fine \\
\hline $21-F / 44$ & Toxoplasmosis (infectious) & Fine \\
\hline $22-M / 20$ & Iridocyclitis (noninfectious) & Fine \\
\hline $23-M / 50$ & Toxoplasmosis (infectious) & Medium \\
\hline $24-F / 32$ & Iridocyclitis (noninfectious) & Medium \\
\hline $25-M / 40$ & Vogt-Koyanagi-Harada (noninfectious) & Large \\
\hline
\end{tabular}

sed as a percentage ${ }^{(16)}$. Previous studies with centre-dot methods reported that while the average values recorded were similar (for the same sets of images), the range of COV values could differ by around 20 per cent ${ }^{(17-18)}$ or even more than this ${ }^{(19)}$, leading that the agreement between COV data was weak. In this study the COV was close in both uveitis groups, it can be reliably used to generate useful data on cell area and cell density, however it should be used cautiously for polymegathism estimations $^{(16)}$.

A recent Brazilian study related the importance of the Cells Analyzer ${ }^{\circledR}$ software for corneal specular microscopy; its using produced representative, standardized and reproducible results in normal endothelium ${ }^{(20)}$; however such software should not be applicable in our study due to endothelial abnormalities presented in our sample.

\section{CONCLUSION}

The clinical applicability of specular microscopy in patients with infectious and noninfectious uveitis can be an useful tool to evaluate the corneal endothelium in the presence of KP, however the handicap of the specular image formation might not be discarded in some cases, probably related to distribution, size or nature of the KP. In this study the differences found were not clinically meaningful, however the uveitis in various degrees of intraocular inflammation and the relatively small number of patients in each clinical category indicates that further studies can be required to evaluate the morphology of endothelial cells in the vicinity of KP.

\section{RESUMO}

Objetivo: Avaliar o endotélio corneano na presença de precipitados ceráticos em pacientes portadores de uveítes infecciosas e não-infecciosas com emprego da microscopia especular de não-contato. Métodos: Prospectivamente foram incluídos 25 pacientes com média de idade de 40,5 ( $\pm 14,2$ anos). Os pacientes foram divididos em dois grupos de acordo com a etiologia da uveíte. O microscópio especular Topcon SP-2000P foi usado para capturar imagens endoteliais. As variáveis densidade endotelial, área celular média e coeficiente de variação das células foram analisados estatisticamente. Resultados: Dos 25 pacientes incluídos no estudo, 16 (44\%) olhos apresentavam uveítes infecciosas, 19(53\%) uveítes não-infecciosas e 1 (3\%) olho foi excluído devido à impossibilidade de obtenção da reflexão especular. A densidade endotelial média foi $2.628 \pm 204 \mathrm{cel} / \mathrm{mm}^{2}$ no grupo infeccioso e $2.622 \pm 357 \mathrm{cel} / \mathrm{mm}^{2}$ no não-infeccioso. As áreas celulares média nos grupos infeccioso e não-infeccioso foram respectivamente $385 \pm 31 \mu \mathrm{m}^{2} \mathrm{e}$ $390 \pm 60 \mu \mathrm{m}^{2}$. Os coeficientes de variação das áreas celulares adjacentes aos precipitados ceráticos foram $26,36 \pm 3,44$ no infeccioso e 27,69 4,61 no não-infeccioso. As diferenças 
encontradas entre os grupos em todas as variáveis não foram estatisticamente significantes ( $\mathrm{p}<0,005 /$ Mann-Whitney Teste). Conclusão: A aplicabilidade clínica da microscopia especular em pacientes com uveítes pode ser útil na avaliação endotelial na presença de precipitados ceráticos, entretanto não podemos descartar as limitações em alguns casos em que a reflexão especular se torna impossível. As diferenças encontradas não foram significativas entre os grupos estudados, entretanto os vários níveis de inflamação ocular e o número relativamente pequeno de pacientes, indicam que novos estudos possam ser desenvolvidos para avaliação da morfologia endotelial.

Descritores: Topografia da córnea; Epitélio posterior; Uveíte; Microscopia/métodos; Precipitação

\section{REFERENCES}

1. Dick AD. Immune mechanisms of uveitis: insights into disease pathogenesis and treatment. Int Ophthalmol Clin; 2000;40(2):1-18.

2. Muccioli C, Belfort R Jr. Cataract surgery in patients with uveitis. Int Ophthalmol Clin. 2000;40(2):163-73

3. Forster D. General approach to the uveitis patient and treatment strategies. In: Yanoff M, Ducker J, editors. Ophthalmology. $2^{\text {nd }}$ ed. St. Louis: Mosby; 2004. p.1115-20.

4. Nussemblatt R, Whitcup S, Palestine A. Uveitis, fundamentals and clinical practice. $2^{\text {nd }}$ ed. St. Louis: Mosby; 1996.

5. Hara M, Morishige N, Chikama T, Nishida T. Comparison of confocal biomicroscopy and noncontact specular microscopy for evaluation of the corneal endothelium. Cornea. 2003;22(6):512-5.

6. Módis L Jr, Langenbucher A, Seitz B. Corneal endothelial cell density and pachymetry measured by contact and noncontact specular microscopy. J Cataract Refract Surg. 2002;28(10):1763-9.
7. Corneal endothelial photography. Three-year revision. American Academy of Ophthalmology. Ophthalmology. 1997;104(8):1360-5.

8. McCarey BE, Edelhauser HF, Lynn MJ. Review of corneal endothelial specular microscopy for FDA clinical trials of refractive procedures, surgical devices and new intraocular drugs and solutions. Cornea. 2008;27(1):1-16.

9. Brooks AM, Grant G, Gillies WE. The use of specular microscopy to investigate unusual findings in the corneal endothelium and its adjacent structures. Aust N Z J Ophthalmol. 1988;16(3):235-43.

10. Brooks AM, Grant G, Gillies WE. Differentiation and assessment of corneal endothelial changes associated with diseases of the anterior segment of the eye. Aust N Z J Ophthalmol. 1987;15(1):65-70.

11. Stevenson R, Kirkness CM. A comparison of contact and non-contact specular microscopy in quantifying corneal morphology [abstract]. Invest Ophthalmol Vis Sci. 1994;35:S1598.

12. Sugar A. Clinical specular microscopy. Surv Ophthalmol. 1979;24(1):21-32.

13. Pillai CT, Dua HS, Azuara-Blanco A, Sarhan AR. Evaluation of corneal endothelium and keratic precipitates by specular microscopy in anterior uveitis. Br J Ophthalmol. 2000;84(12):1367-71.

14. Benetz BA, Gal RL, Ruedy KJ, Rice C, Beck RW, Kalajian AD, Lass JH; Cornea Donor Study Group. Specular microscopy ancillary study methods for donor endothelial cell density determination of cornea donor study images. Curr Eye Res. 2006;31(4):319-27.

15. Van Schaick W, Van Dooren BT, Mulder PG, Völker-Dieben HJ. Validity of endothelial cell analysis methods and recommendations for calibration in Topcon SP-2000P specular microscopy. Cornea. 2005;24(5):538-44.

16. Doughty MJ. Could the coefficient of variation (COV) of the corneal endothelium be overestimated when a centre-dot method is used? Clin Exp Optom. 2008;91(1):103-10.

17. Ohno K, Nelson LR, McLaren JW, Hodge DO, Bourne WM. Comparison of recording systems and analysis methods in specular microscopy. Cornea. 1999; 18(4):416-23.

18. De Sanctis U, Machetta F, Razzano L, Dalmasso P, Grignolo FM. Corneal endothelium evaluation with 2 non-contact specular microscopes and their semiautomated methods of analysis. Cornea. 2006;25(5):501-6.

19. Benetz BA, Diaconu E, Bowlin SJ, Oak SS, Laing RA, Lass JH. Comparison of corneal endothelium image analysis by Konan SP8000 non-contact and BioOptics Bambi systems. Cornea. 1999;18(1):67-72.

20. Melo CM, Santos PM, Santos RC, Abib FC. Utilização do programa Cells Analyser ${ }^{\circledR}$ no estudo comparativo entre imagens do endotélio de córneas obtidas por microscopia especular. Arq Bras Oftalmol. 2008;71(1):79-82. 